\title{
ヒト外尿道括約筋の生化学的研究
}

\begin{tabular}{|c|c|c|c|c|}
\hline & 医科大 & 谷尿器科 & （主任： & 直教授 \\
\hline 德中 & 荘平 & 藤井 & 敬三 & 岡村 \\
\hline 宮田 & 昌伸 & 金子 & 茂男 & 八竹 \\
\hline
\end{tabular}

\section{BIOCHEMICAL ANALYSIS OF HUMAN EXTERNAL URETHRAL SPHINCTER}

\author{
Sohei Tokunaka, Hiromitsu Fujii, Kiyoharu Okamura, Miasanobu Miyata, \\ Shigeo Kaneko and Sunao Yachiku \\ Department of Urology, Asahikawa Medical College \\ (Director: Prof. Sunao Yachiku)
}

Human external urethral sphincter (EUS) muslce was isolated from urethrae obtained in surgery by glycerination. Electrophoretic samples were made from the isolated EUS muscle and pyrophosphate electrophoresis and two-dimensional electrophoresis were performed. Denatured myosin isozymes and myosin light chain components from EUS muscle were analysed by pyrophospahte electrophoresis and two-dimensional electrophoresis, respectively. Human EUS was concluded to be comprised with both fast twitch and slow twitch muscle fibers. The distribution of fast and slow myosin in EUS was examined in six cases. The distribution was various from case to case. In no case the percentage of slow twitch myosin was less than $38.8 \%$.

\footnotetext{
要旨：膀胼尿道全摘除術で得た男子尿道より外尿道括約筋の筋線維を分離し, 電気泳動用試料を調製し た。ピロリン酸電気泳動法と 2 次元電気泳動法を用いて未変性ミオシンのアイソザイムとミオシン軽鎖 を検討した結果, ヒト外尿道括約筋は, 速筋線維と遅筋線維の両者によって構成されることが示された。 速筋型ミオシンと遅筋型ミオシンの量比を 6 症例で検討したところ, それらの量比は個々の症例により 大きく異なったが，遅筋型ミオシンが $38.8 \%$ 以下のものは見られなかった。
}

\section{緒言}

括約筋部尿道には，尿道粘膜をとり囲む，不随意筋 の平滑筋と，これをさらに外側よりとり囲さ，随意筋 の横紋筋よりなる外尿道括約筋 (EUS) が存在する。 尿道括約筋は, 膀胱蓄尿時には持続的に緊張を続けて 尿の continence を保ち，排尿時には，膀胱収縮に合わ せて速やかに弛緩してスムーズな排尿を遂行する11. 随意筋である EUS は, 近年のウロダイナミクス検査 法の発達ととるに，尿道括約筋機構の主体であると考 えられてきたが, その機能は, 不随意筋の平滑筋蔵器 である膀胱の機能と密接に関連しており ${ }^{2)}$, 他の部位 の横紋筇と異なった特殊な構造をしていることが知ら れて来だ)4)。

ヒトを含めた哺乳類の横紋筋線維は，速やかに収縮 出来るが，疲労しやすい速筋線維と，ゆっくり収縮す るが，疲労しにくい遅筋線維に大別される。速筋線維 は, anerobic-glycolytic, 遅筋線維は, aerobic- oxidativeな代謝をして, motoneuron の形態も全く異 なる5)。

一般の横紋筋は, 速筋線維と遅筋線維が混合して出 来ている。すなわち, 人体で最も速やかに収縮する必 要がある外眼筋は, 速筋線維 $85 \%$, 遅筋線維 15\%で構 成され，径骨のそばにあって立位姿勢を保持するため 緊張を持続する必要があるヒラメ筋は, 速筋線維11\%, 遅筋線維 $89 \%$ で構成されている ${ }^{6)}$. 従って, 筋肉の筋線 維の構成は，その筇肉の機能により異なっており，ま た, 筋線維の構成を知ることで, その筋肉の機能を知 ることが可能であると思われる。

従来, 横紋筋の筋線維型は, 1950年代初めに Padycula \& Hermannにより開発された, ATPase 染 色法7)をはじめとする組織化学的方法8)で行なわれて きたが, 1970年代後半より。速筋線維と遅筋線維では, ATPase 活性だけでなく，ミオシン、トロポニンCな どの筋構成タンパク質も異なることがわかり ${ }^{91}$, これ 
らの筇構成タンパク質を生化学的に分析することでも 筋線維型を知ることが可能となった。

ヒトEUSの筇線維型を研究することはEUSの機 能, 特性を解明する上で大変役立つと考兄られるが, 現在まで, 組織化学的あるいは, 形態学的研究が数 編310111)報告されているだけである。我々は，かって， 家鬼EUSを, 生化学的, 組織化学的に分析し, 家鬼 EUS は, 速筋線維 $80 \%$, 遅筋線維 $20 \%$ で構成される速 筋であることを報告している(2) 14)が，今回は，ヒト EUS の筋線維型を生化学的に検討した。

\section{材料と方法}

ヒトEUSとヒト腹直筋の採取と処理：膀胱腫瘍患 者に叔ける, 膀脱尿道全摘除術で得た男子尿道を, 液 体窒素でただちに凍結し, $-80^{\circ} \mathrm{C}$ のリーザーで保存 した。この凍結保存した尿道から, EUS を含む部分(前 立腺の遠位半分々前部尿道の近位端 $1 \mathrm{~cm}$ )を切り出し, 凍結状態のまま, 横断方向に $0.3 \mathrm{~mm}$ の厚さに薄切し, $50 \%$ グリセリン, $50 \%$ Relaxing buffer (RB) : 0.1M $\mathrm{KCl} / 2 \mathrm{mM} \quad \mathrm{MgCl}_{2} / 2 \mathrm{mM} \quad$ EGTA/0.1mM Phenyl methyl sulfonyl fluoride (PMSF)/0.01M Trismaleate buffer, pH 6. $8^{15)}$ の中で, $-20^{\circ} \mathrm{C} て ゙, 2$ 週間以 上保存した。この薄切した尿道から実体顕微鏡を用い て $4{ }^{\circ} \mathrm{C}$ の RB の中で可及的に EUS の筋層のみを分離 採取した。分離 EUS は, 位相差顕微鏡で横紋筋である ことを確認した(図 1)，ヒト腹直笳は手術の際に採取 し, 液体窒素でただちに涷結し, $-80^{\circ} \mathrm{C}$ のリーザーで 保存した。

電気泳動用試料の調製：ピロリン酸電気泳動用の粗 ミオシンの調製は, EUS 拉よび腹直筋より，それぞれ， 直接抽出 ${ }^{16)}$ して行なった。EUS 㐨よび腹直筋からの 2 次元電気泳動用試料の調製は, それぞれの筇肉を細切 した後, lysis buffer ${ }^{17)}$ を加光, ミクロガラスホモジナ イザーで充分ホモジナイズした。これらを $600 \times \mathrm{g}, 10$ 分間，遠心した後，上清を泳動用試料とした。泳動用 試料のタンパク質濃度は, 牛血清アルプミンを標準タ ンパク質として Bradford 法 ${ }^{18)}$ で決定した。

電気泳動法：ピロリン酸電気泳動は, Hoh (19) $^{19}$ 準 じて行なった。ゲルのアクリルアミド濃度は $4 \%$ で行 なった。 $80 \mathrm{~V} て ゙ 1$ 時間プレランした後，ゲル1本あた り 4 6 $\mu \mathrm{g}$ の粗ミオシンを重層し， $80 \mathrm{~V} て ゙ 24$ 時間ない し36時間の泳動を行なった。泳動槽は氷水で冷却し， 泳動バッファーは, 泳動中 $2 \sim 3{ }^{\circ} \mathrm{C}$ に維持した。 2 次 元電気泳動は, O'Farrell ${ }^{177}$ に準じて，1次元目に等電 点電気泳動を行ない，2次元目は，1 次元目の等電点
図 1 分離したヒト外尿道括約筋 (EUS) グリセリン 筋の位相差顕微鏡写真。横紋が認められる. Scale $\mathrm{bar}=20 \mu \mathrm{m}$.

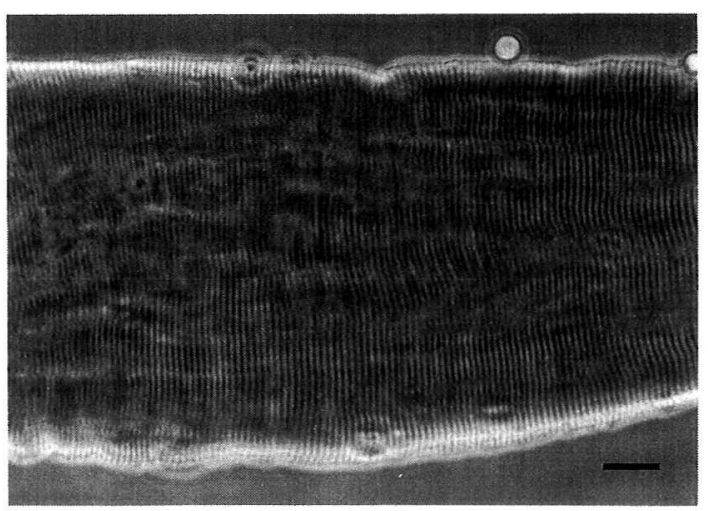

ゲルを重層して, SDS ポリアクリルアミドスラブゲル 電気泳動を行なった，等電点ゲルには $100 \mu \mathrm{g}$ の試料を 重層した。等電点電気泳動は, $400 \mathrm{~V} て ゙ 12$ 時間行なった 後, $800 \mathrm{~V}$ で 1 時間通電して終了した. 2 次元目のゲル は, 厚さ $1 \mathrm{~mm}$ で, 深さ $2.5 \mathrm{~cm}$ のアクリルアミド濃度 $4.5 \%$ 濃縮ゲルとアクリルアミド濃度15\%の分離ゲ ルからなり, 電気泳動は, 最初 2 時間を $5 \mathrm{~mA}$, その後 $20 \mathrm{~mA}$ で終了まで行なった。泳動後のゲルは, ピロリン 酸電気泳動, 2 次元電気泳動子もに0.13\%, Coomassie Brilliant Blue R/45\%ェタノール/9.2\%酢酸で染色 し， $5 \%$ エタノール $/ 7.5 \%$ 酢酸で脱染色した。

腹直筋粗ミオンンからの速筋型㐨よび遅筋型ミオシ ンの分離精製：8本のピロリン酸ゲルに，それぞれ， $4 \mu \mathrm{g}$ の腹直筋粗ミオシンを重層し，ピロリン酸電気泳 動を行なった。ゲルを0.13\%Coomassie Brilliant Blue $\mathrm{R} / 45 \%$ エタノール $/ 9.2 \%$ 酢酸で 1 時間染色し, 水洗 後, 速筋型ミオシンおよび遅筋型ミオシンのバンドを 切り出し, これらのゲル片から Allington ら ${ }^{20)}$ に準じ て電気泳動によりタンパク質の抽出を行なった。抽出 バッファーは, $25 \mathrm{mM}$ Tris/192mM グリシン/0.1\% $\mathrm{SDS}, \mathrm{pH} 8.4$ で $4 \mathrm{~mA}$ の通電で, 12時間行なった。抽出

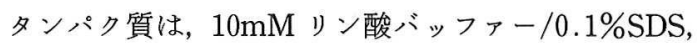
$\mathrm{pH} \quad 7.0$ で 5 時間透析後, さらに 12 時間凍結乾燥し, lysis bufferに溶解して 2 次元用試料とした。

EUS ミオシン軽鎖2F とミオシン軽鎖2S の量比の 検討：EUSより調製した 2 次元泳動用試料を前述の よ5に 2 次元泳動した後, ゲルを染色, 脱染色し, 速 筋型ミオンン軽鎖 $2 \mathrm{~F}$ と遅筋型ミオンン軽鎖 $2 \mathrm{~S}$ のス ポットを切り出した. Fenner ら ${ }^{21}$ に準じて, 切り出し 
たゲル片から Coomassie Brilliant Blue R をピリジン 溶液で抽出し，牛血清アルブミンを標準として $605 \mathrm{~nm}$ に括ける吸光度を測定し, EUS ミオシン軽鎖の量比を 算出した。

\section{結 果}

腹直筋と EUS から調製した未変性ミオシンのピロ リン酸電気泳動：図 2 に示すよらに腹直筋のピロリン 酸ゲル（ゲルA）では, Hoh ら ${ }^{22)}$ の報告と同様に, 速 筋型ミオシンのアイソザイムである FM1, FM2, FM3 の 3 本のバンドと遅筋型ミオシンのアイソザイムの $\mathrm{SM}$ のバンドを認める。次に, 代表的な異なる 2 症例の EUS のピロリン酸ゲルでは, 1 例では(ゲル B), 速筋 型ミオシンアイソザイムのバンドが無く, 遅筋型ミオ シンアイソザイム $\mathrm{SM}$ のみがあり，他の 1 例では（ゲ ルC), 腹直筋のゲルと同様に, 速筋型ミオシンの FM1，FM2，FM3の 3 本のバンドと遅笳型ミオシンの SM のバンドを認める.

ヒト腹直笳の 2 次元電気泳動：図 3 にヒト腹直筋粗 ミオシンより分離精製した速筋型ミオシン（図 $3 \mathrm{~A}$ ) と 遅筋型ミオシン(図 3B)の 2 次元電気泳動結果を示す. 図 $3 \mathrm{~A}$ では, 速筋型ミオシン軽鎖 $1 \mathrm{~F}, 2 \mathrm{~F}, 3 \mathrm{~F}$ のスポッ トのみが認められ, 遅筋型ミオシン軽鎖1S, 1'S, 2S の スポットが認められない。これに対し, 図 3Bでは, 遅 筋型ミオシン1S, 1'S, 2S のスポットとともに速筋型ミ

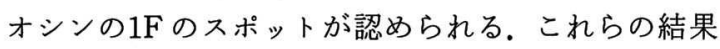
は，図は割愛するが，同時に行なった銀染色でも確か められた。 以上の結果より, ヒト腹直筋粗ミオシンの 2 次元電気泳動ゲルにおけるタンパク質スポットを図 4 のように同定した。

ヒト EUS 2 次元電気泳動用試料の 2 次元電気泳 動：図 5 にヒトEUS 2 次元電気泳動用試料の 2 次元 電気泳動結果を示す. 図 5A の症例では, 遅筋型ミオシ ン軽鎖1S, 1'S, 2S のスポットを認めるが, 速筋型ミオ シン軽鎖は $1 \mathrm{~F}$ のスポットのみがあり, $2 \mathrm{~F}$ と $3 \mathrm{~F}$ のス ポットを認めない。図 $5 \mathrm{~B}$ と図 $5 \mathrm{C}$ の 2 症例では, とも に速筋型ミオンン軽鎖 $1 \mathrm{~F}, 2 \mathrm{~F}, 3 \mathrm{~F}$ のスポットと遅筋型 ミオシン軽鎖1S, 1'S, 2S のスポットを認める。ただし, 図 5B の症例では, 遅筋型ミオシン軽鎖 $1 \mathrm{~S}, 1$ 'S, $2 \mathrm{~S}$ の スポットが速筋型ミオンン軽鎖 $1 \mathrm{~F}, 2 \mathrm{~F}, 3 \mathrm{~F}$ のスポット より濃く染色されているが, 図 $5 \mathrm{C}$ の症例では, 速筋型 ミオシン軽鎖 $1 \mathrm{~F}, 2 \mathrm{~F}, 3 \mathrm{~F}$ のスポットが遅筋型ミオンン 軽鎖1S, 1'S , 2S のスポットより濃く染色されている. また, トロポニンCのスポットも図 5Bでは, 遅筋型卜 ロボニンCが速筋型トロボニンCより濃く染色され
図 2 ピロリン酸ゲル電気泳動写真 ( $4 \%$ ゲル). A. ヒト腹直筋の粗ミオシン. 速筋型ミオシンアイソザ イムの FM1, FM2, FM3の 3 バンドと遅筋型ミオシ ンアイソザイムの SM バンド*が認められる. B. ヒ 卜外尿道括約筋粗ミオシン。遅筋型ミオシンアイン ザイムの SM バンドのみを認め, 速筋型ミオシンフ イソザイムのバンドを認めない．C．Ｂとは異なっ た症例から得たヒト外尿道括約筋粗ミオシン. 腹直 筋と同様に速筋型ミオシンアイソザイムの FM1, FM2, FM3の 3 バンドと遅筋型ミオシンアイソザイ ムの SM バンドを認める.ゲル A とゲル B は同時 に電気泳動したが,ゲルCは異なった泳動である。 * $\mathrm{SM}$ バンドは他の報告者の SM1, SM2の 2 バンドに 相当する ${ }^{22)}$.

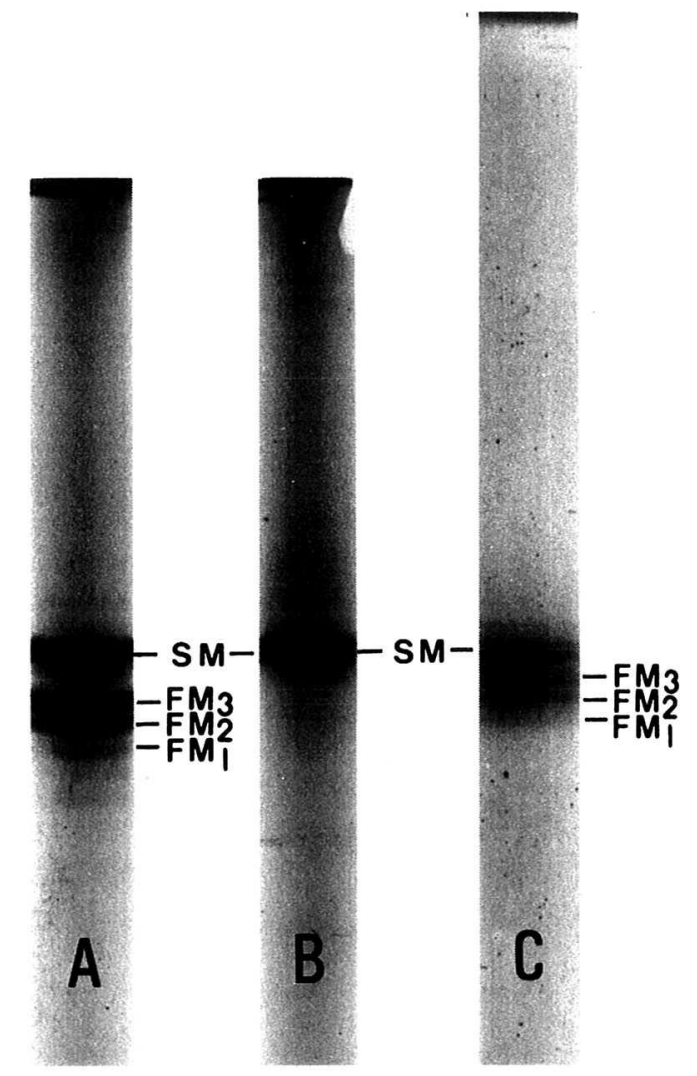

ているのに, 図 5Cでは, 速筋型トロボニン C が遅筋型 トロボニンCょり濃く染色されている。

表 1 に 6 症例のヒトEUS 2 次元電気泳動用試料の 2 次元電気泳動ゲルから切り出した速筋型ミオシン軽 鎖 $2 \mathrm{~F}$ と遅筋型ミオシン軽鎖 $2 \mathrm{~S}$ のモル比を示した。 6 症例から得た EUS 試料を 2 次元電気泳動して, 染色 後, ゲルのミオシン軽鎖スポットを切り出し, ピリジ ン溶液で染色剂の Coomassie Brilliant Blue Rを溶出 
図 3 ヒト腹直筋より精製した速筋型ミオシンと遅筋 型ミオシンの 2 次元電気泳動写真. A. 速筋型ミオ シン, $1 \mathrm{~F}, 2 \mathrm{~F}, 3 \mathrm{~F}$ の速筋型ミオシン軽鎖のみを認め る. B. 遅笳型ミオンン. $1 \mathrm{~S}, 1$ 'S, $2 \mathrm{~S}$ の遅筋型ミオ シン軽鎖とともに速筋型ミオンン軽鎖の $1 \mathrm{~F}$ を認め る.

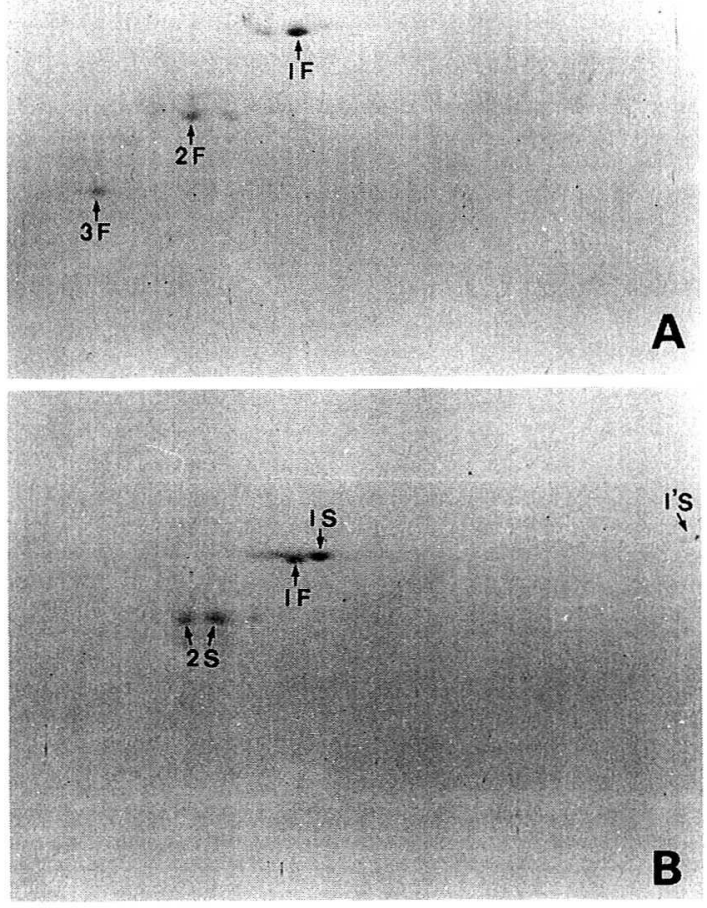

図 4 ヒト腹直筋の 2 次元電気泳動写真. ゲル左が酸 性側，1F，2F，3F：速筋型ミオシン軽鎖．1S，1'S, $2 \mathrm{~S}$ ：遅筋型ミオシン軽鎖. FTC, STC：速筋型トロ ポニンC抽よ゙，遅筋型トロポニンC， A：アクチ ソ, $\mathrm{TM} \alpha, \mathrm{TM} \beta$ : トロポミオシン.

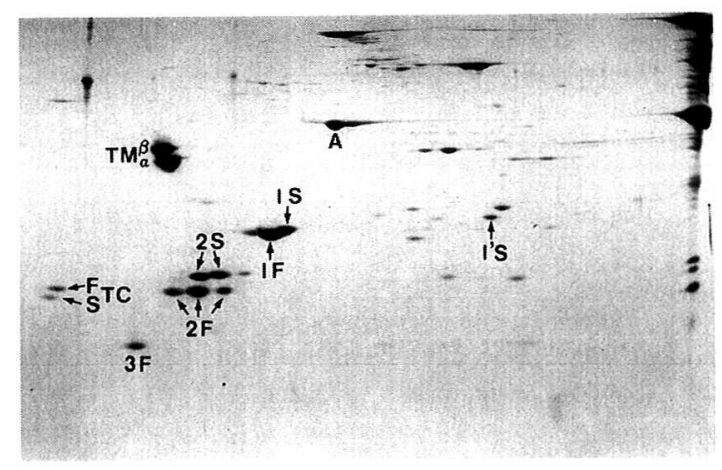

図 5 七ト外尿道括約筋 (EUS) の 2 次元電気泳動写 真. A. 症例 S.T. 63 歳。遅笳型ミオシン軽鎖 $1 S$, 1' $\mathrm{S}, 2 \mathrm{~S}$ ととも速筋型ミオシン軽鎖 $1 \mathrm{~F}$ を認める. 速 筋型ミオシン軽鎖 $2 \mathrm{~F}, 3 \mathrm{~F}$ は認められない, B. 症例 Y.W. 69歳. 速筋型ミオシン軽鎖 $1 F, 2 F, 3 F$ と遅筋 型ミオシン軽鎖 $1 \mathrm{~S}, 1$ 'S, $2 \mathrm{~S}$ を認めるが, 遅筋型ミオ シン軽鎖のスポットの方が速筋型ミオシン軽鎖のス ポットより濃く染まっている.トロポニンC も遅筋 型が速筋型より濃く染まっている.C. 症例 T.F. 54 歳. 速筋型ミオシン軽鎖 $1 \mathrm{~F}, 2 \mathrm{~F}, 3 \mathrm{~F}$ と遅筋型ミオシ ン軽鎖1S, 1'S, 2S を認めるが, 速筋型ミオシン軽鎖 のスポットの方が遅筋型ミオンン軽鎖のスポットよ り濃く染まっている.トロポニンC も速筋型が遅笳 型より濃く染まっている。
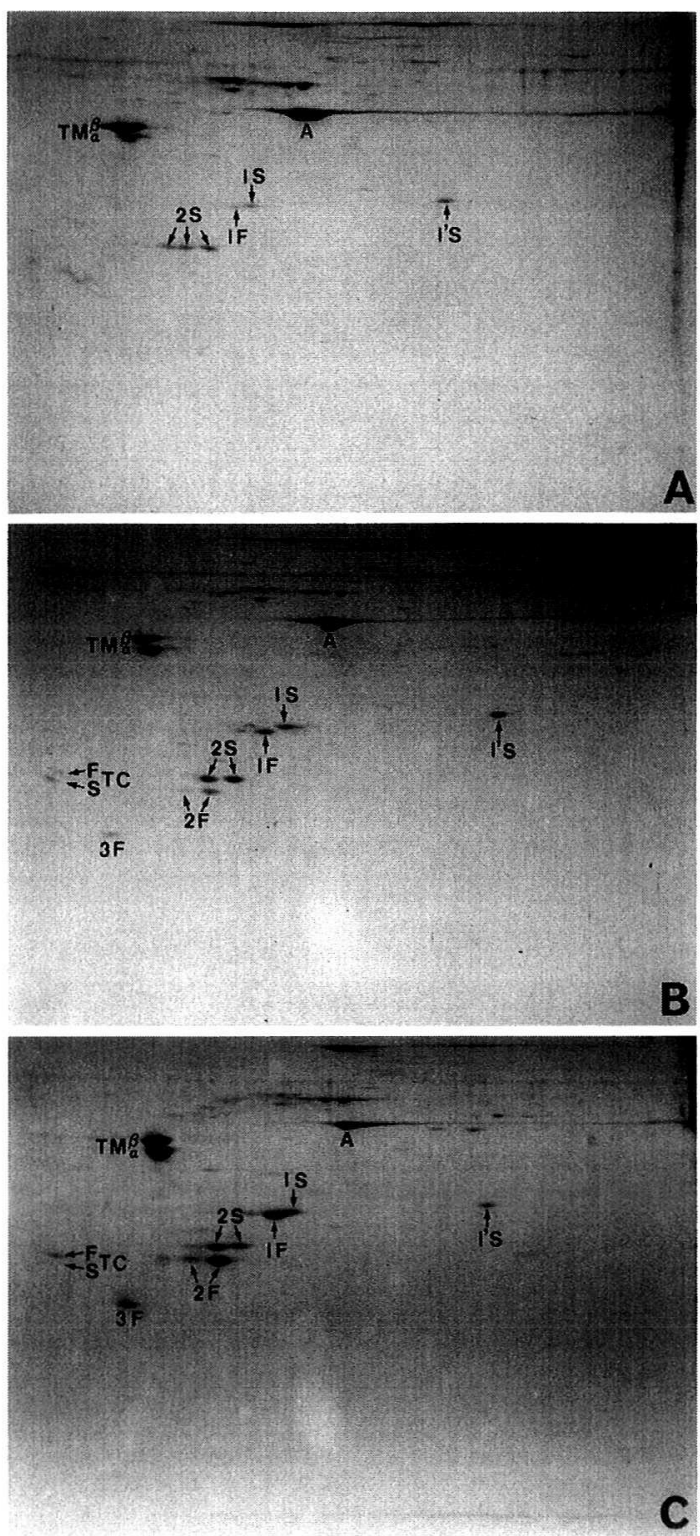
表 1 ヒト外尿道括約筋 (EUS) に打ける速筋型 ミオンン軽鎖 $2 \mathrm{~F}$ と遅筋型ミオシン軽鎖 $2 \mathrm{~S}$ の量比.

( 1 症例 6 枚のゲルを測定. mean $\pm 1 \mathrm{SD}$ )

\begin{tabular}{|c|c|c|c|}
\hline & 例 & $\begin{array}{c}\text { 遅筋型ミオシン } \\
\text { 軽鎖 } 2 \mathrm{~S}\end{array}$ & $\begin{array}{c}\text { 速筋型ミオシン } \\
\text { 軽鎖 } 2 \mathrm{~F}\end{array}$ \\
\hline S. I. & 53歳男子 & $83.5 \pm 9.5 \%$ & $16.5 \pm 9.5 \%$ \\
\hline T. F. & 54歳男子 & $38.8 \pm 2.0 \%$ & $61.2 \pm 2.9 \%$ \\
\hline T. N. & 61歳男子 & $50.6 \pm 2.8 \%$ & $49.4 \pm 2.8 \%$ \\
\hline S. T. & 63歳男子 & $95.0 \pm 2.0 \%$ & $5.0 \pm 2.0 \%$ \\
\hline M. H. & 67歳男子 & $73.4 \pm 1.8 \%$ & $26.7 \pm 1.8 \%$ \\
\hline S. S. & 71歳男子 & $39.8 \pm 0.5 \%$ & $60.2 \pm 0.5 \%$ \\
\hline
\end{tabular}

し, 速筋型ミオンン軽鎖 LC2F と遅筋型ミオシン軽鎖 LC2S のモル比を染色剂の量から算出した。ミオシン 1 分子は 4 個のミオシン軽鎖を持ち，その内 2 個は軽 鎖 2 で(速筋線維では, LC2F, 遅筋線維では, LC2S), 残り 2 個の軽鎖は軽鎖 2 以外の軽鎖（速筋線維では, LC1F と LC3F, 遅筋線維では, LC1S と LC1'S あるい は LC1F)から構成される ${ }^{23)}$. 従って, 速筋型ミオシン 軽鎖 LC2F と遅筇型ミオシン軽鎖 LC2S のモル比は, 速筋型ミオンンと遅筋型ミオンンのモル比と同一とな り, 速筇線維と遅筋線維の量比を反映すると考兄られ る. 検討症例は 6 例と少ないが，速筋型ミオシンと遅 筋型ミオシンの量比は, 症例により大きく異なること がわかった。

\section{考案}

EUS の生化学的研究のためには, 純度の高い筇肉組 織を得ることが必要である。一般の横紋筋（骨格筋） は，多数の筋細胞（筋線維）が小量の線維性結合組織 により結びつけられた筋束を形成している24)ので, 純 度の高い筋肉組織が容易に得られるが，ヒト EUSは， 骨格筋と異なって，筋束を形成しないで個々の筋線維 が厚い結合組織の中に散在しており，また平滑筋であ る内尿道括約筇と隣接して存在する ${ }^{25}$. 従って, 標本を そのままホモジナイズした場合，結合組織に妨害され て筋構成タンパク質の抽出が困難であること, また平 滑筋成分の混入が避けられないことが問題となった。 我々は，採取したEUS を含む尿道をグリセリン処理 することでEUS の横紋筋線維を周囲の線維性結合組 織や平滑筋から分離採取することが出来た。グリセリ ン処理は, 細胞膜に多数の孔をあけ, 線維性結合組織 を軟らかくして, EUS の筋線維の採取を容易にする. 一方, グリセリン処理により, EUS 筋細胞膜も破壊さ れ, 代謝系に関連する可溶性タンパク質は失われるが,
収縮構造タンパク質は，生筋とほぼ同様の状態で保持 されている ${ }^{26)}$ ため今回の研究目的によく合うと考兄ら れた。

ミオシン 1 分子は, 2 本のミオシン重鎖と 4 本のミ オンン軽鎖から構成される ${ }^{22)}$. Hoh $5^{19)}$, d'Albis $5^{27)}$ によって考案されたピロリン酸電気泳動法は, ミオシ ンを重鎖と軽鎖に分けずにミオシン分子を未変性のま ま電気泳動できるのが特徵である。成人の骨格筋ミ才 シンは，ピロリン酸ゲルで下から上に FM1，FM2， FM3, SM1, SM2の 5 本のバンドに分けられる. FM1, FM2，FM3は，それぞれ速筋型ミオシンのアイソザイ ム，SM1，SM2は，それぞれ遅筋型ミオシンのアイン ザイムであり,それぞれのアインザイムの量比は, 色々 な筋肉により異なっていることが知られている，遅筋 型ミオシンアイソザイム SM1, SM2の 2 本のバンドは 非常に近接した部位にあるため，特に，我々の使った $4 \%$ ゲルでは分離が悪いので 1 本の SM バンドとし て表示した(図 2$)$. 速筋線維は, 速筋型ミオシンアイ ソザイムだけを持ち，遅筋線維は，遅筋型ミオシンア イソザイムだけを持つ。また胎児期のミオシンアイン ザイムは，成人のものとは全く異なっていることも分 かっている22). 我々は，一般の骨格筋である腹直筋と， EUS から調製した試料を比較検討した. 腹直筋は，小 児および成人の数例で行なったが，図 2 ゲルAのよ に, いずれも速筇型ミオシンアイソザイムの 3 本のバ ンドと遅筋型ミオシンアイソザイムのバンドがみられ た。腹直笳は，文献的には，速筋線維 $50 \%$, 遅筋線維 $50 \%$ で構成される6)とされ，今回の結果は，このことを 裏づけるものと考兄られた. EUS では, 図 2 ゲル B の ように，遅筋型ミオシンアインザイムのバンドのみが みられるものと，図 2 ゲルCのように，腹直筋と同様 に速筋型, 遅筋型両方のミオシンアイソザイムが存在 するものがあった。従って，前者の EUS は， ほとんど 遅筋線維のみで構成され，後者の EUS は, 速筋線維と 遅筋線維の両者で構成されていると考兄られた。

2 次元電気泳動法によるヒト横紋筇構成タンパク質 の検討は, 1978年頃より行なわれてきた ${ }^{28) 29) .} 2$ 次元電 気泳動用試料は，調製の段階でミオシン分子が軽鎖と 重鎖に分解される。ミオシン重鎖は，分子量が大きす ぎてゲル内にほとんど入ってこないため，2 次元電気 泳動法によるミオンンの分析は，もっぱらミオンン軽 鎖で行なわれる。一般に, 速筋線維は速筋型ミオシン 軽鎖 LC1F，LC2F，LC3F の 3 種類をもち，遅筋線維 は遅筋型ミオシン軽鎖 LC1S，LC1'S，LC2S の 3 種類 
を持つ，現在まで報告されている文献でミオシン軽鎖 のスポットの位置が報告者により異なる28)29)ため, 我々は, 腹直筋粗ミオシンをピロリン酸電気泳動して, 速筋型ミオシンと遅筋型ミオシンに分け, これらを試 料として 2 次元電気泳動を行ない, 2 次元電気泳動ゲ ルに抢けるミオシン軽鎖のスポット位置を決定した (図 3，4). その結果，ヒト速筇型ミオシン軽鎖 LC1 $\mathrm{F}$ と遅筋型ミオンン軽鎖 LC1S は井常に接近して存在 乙, かつ他の哺乳類骨格筋線維と異なって遅筋型ミオ シンが遅筋型ミオシン軽鎖 LC1S，LC1'S，LC2S だけ でなく, 速筋型ミオシン軽鎖 $\mathrm{LC1F}$ をも持つことが明 らかとなった。 この事実は, 他の研究者によっても確 認されている301311.

従来の EUS 研究は, 猫を使って電気生理学的方法 で行なわれたものが汪とんどで, EUS を遅筋として記 載しているものが多い。ヒト EUS も動物実験の結果 と尿の continence を保持する機能から推定して遅筋 と考えられてきた。

実際に, EUS の筋肉自体を筋肉の代謝系酵素の組織 化学的分析, 筋収縮構造タンパク質の生化学分析, あ るいは電子顕微鏡を用いた超微構造の検討などを行 なった研究はまだ非常にすくない, 我々は, 家鬼 EUS を生化学的, 組織化学的に検討して速筇線維 $80 \%$, 遅 筋線維 $20 \%$ で構成される速筋であることを報告した。

Bazeed ら ${ }^{22}$ は, 犬 EUS を ATPase 染色を主体とする 組織化学的方法で検討し, 速筋線維 $65 \%$, 遅筋線維 $35 \%$ で構成され，遅筋線維の比率は，EUS の内側ほど高い と報告している. 我々も家鬼EUSのATPase 染色で EUS 内側ほど遅筋線維の比率が高をることを確認し ている ${ }^{14)}$. Bazeedらは, さらに膀胱にストレスの加 わった状態では, EUS 部の尿道内圧がすみやかに上昇 すること, 仙骨神経根に高周波の電気刺激を加兄, 速 筋線維を疲労させた状態でも EUS 部の尿道内圧が一 定以下に下がらないことから, 疲労しにくく, 持続的 に緊張を保つ遅筋線維が安静時に打ける尿の continenceを主に維持しており, 疲労し易い速筇線維は, ス トレス時に扣ける急激なEUS の緊張の上昇や，尿線 の中断に関与すると推定している.

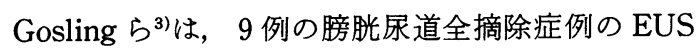
を透過型電子顕微鏡とATPase 染色法で検討したと ころ, 純粋に遅筋線維のみで構成された遅筋であると 報告している。しかし，Schr $\phi \operatorname{der} ら^{10)} は ， 3$ 症例の剖 検例を ATPase 染色法で検討し, EUS は速筋線維と 遅筋線維の両者で構成されると報告している。従って,
ヒトEUS の筋線維型については, 今だ定説がなく, 議 論のあるところである.

今回の我々の検討では, ピロリン酸電気泳動による 末変性ミオシンも，2 次元電気泳動によるミオシン軽 鎖も速筋型, 遅筇型の両方が認められた。試料に用い た EUS 筋線維は，EUS 部尿道全体から可及的完全に 採取し，その全量を使って試料を調製したため, 試料 内の速筋型, 遅筋型ミオシンの量比は, そのまま EUS 全体の速筋線維, 遅筋線維の量比を反映することにな る. 従って, ヒト EUS は, 速筇線維, 遅筋線維の両者 から構成されることは間違いない，後日発表する予定 であるが，我々は，この事実を ATPase 染色でも確か めている.

ヒトEUS の速筋型, 遅筋型ミオシンの量比, 即ち, 速筋線維と遅筋線維の量比が個体により著しく異なる のは，他の動物では見られない現象であり，ヒトEUS の特徵と思われる。一般に, 個々の横紋筋の速筋線維 と遅筋線維の量比は, 生まれつき決まっており, 生後 の運動負荷などのトレーニングによっては変化しない

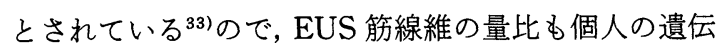
素因，あるいは，EUS の神経支配が形成される胎児期 の母体抢よび胎児環境における種々の要因により異 なってくるものと考えられる。本研究で検討し得た症 例はいずれも男子で50歳以上であったが,女子拉よび, より若年の症例の検討も必要であろう. EUS の遅筋型 ミオシンの比率は, 症例により $95.0 \%$ から $38.8 \%$ まで 色々であった。換言すれば, 速筋型ミオシンが $5 \%$ と 非常に少ない症例はあったが, 遅筋型ミオシンの比率 が38.8\%以下の症例はないことから，ヒト EUSにお いても安静時の尿の continence の維持には, 遅筇線維 が主に関与していると推定される.ヒトEUS の遅筋 線維の比率が，家鬼，犬より高い理由の一つとして， 家鬼, 犬が四足行歩行するのに対し，ヒトは，二足歩 行するため, 膀胱に対して膀胱径部，尿道が，家鬼， 犬などより下方に位置し, 安静時においてもょり強い 閉鎖圧を必要とするためと思われる。ヒトおよび霊長 類の骨盤底筋群も同様の理由で, 他の哺乳類より著し く発達していることが知られている34).

EUS は，骨格筋と同様に随意筋ではあるが，骨格筋 と異なって筋束を形成せず, 起始部, 停止部が無く, 個々の筋線維が線維性結合組織中に散在している ${ }^{25)}$. 神経支配も骨格筋と同様の体性神経ばかりでなく，自 律神経である交感神経, 副交感神経の支配も受け35), 筋 紡錘の存在が証明されない3)など, むしろ平滑筋に近 
い性質を持っている。これらの EUS の特性は, 平滑筋 臓器である膀胼および内尿道括約筋と密接に関連して 機能する必要性から生じたものと考えられる。この, いわば骨格筋と平滑筋両方の性質をかね備えた EUS 横紋筋の筋収縮構造タンパク質が，一般の骨格筋と同 様のものか，あるいは生きている限り拍動し続ける心 藏筋の筋収縮構造タンパク質 ${ }^{36)}$ ような一般の骨格筋 と異なって特殊化した筋収縮構造タンパク質であるの か興味が持たれた。今回の検討の結果, ピロリン酸電 気泳動によるミオシンアイソザイムと 2 次元電気泳動 によるミオシン軽鎖の両方ともEUSは一般の骨格筋 である腹直筋とほぼ同様であることが証明された。

\section{結語}

グリセリン処理により平滑筋成分や結合組織成分を 混入せずにヒト EUSを単離することが出来た。単離 した EUS 横紋筋線維より電気泳動用試料を調製し, ピロリン酸電気泳動と 2 次元電気泳動を行なった。 ヒ トEUSをヒト腹直筋と比較して, ピロリン酸電気泳 動により未変性ミオンンを, 2 次元電気泳動によりミ オシン軽鎖を検討し, ヒト EUSは, 速筋線維と遅筋線 維の両者から構成されることを証明した．6例のヒト EUS の速筋型ミオシンと遅筋型ミオシンの量比を検 討したところ，それらの比率は個体により非常に異 なったが，遅筋型ミオシンが $38.8 \%$ 以下の症例はみら れなかった。

本研究に用いた試料の一部を御提供いただいた近畿大学 医学部泌尿器科教室, 栗田 孝教授, 旭川厚生病院泌尿器 科, 南 茂正医長に深謝いたします。充た, 筇肉の生化学的 研究法全般にわたって御指導いただいた, 本学, 化学教室の 内田幸喜教授，村上梅司博士に深謝いたします。

\section{文献}

1) Kuru, M.: Nervous control of micturition. Physiol. Rev., 45, 425-494, 1965.

2) Fletcher, T.F. and Bradley, W.E.: Neuroanatomy of the bladder-urethra. J. Urol., 119, 153-160, 1978.

3) Gosling, J.A., Dixon, J.S., Critchley, H.O.D. and Thompson, S.-A. : A comparative study of the human external sphincter and periurethral levator ani muscle. Brit. J. Urol., 53, 35-41, 1981.

4) Oelrich, T.M.: The urethral sphincter muscle in the male. Am. J. Anat., 158, 229-246, 1980.

5) Burke, R.E., Levine, D.N., Tsairis, P. and Zajac, F.E. III. : Physiological types and histochemical profiles in motor units of the cat gastrocnemius. J. Physiol., 234, 723-748, 1973.

6) Johnson, M.A., Polgar, J., Weightman, D. and Appleton, D.: Data on the distribution of fibre types in thrity-six human muscles, and autopsy study. J. Neurol. Sci., 18, 111-129, 1973.

7) Padykula, H.A. and Hermann, E.: Factors affecting the activity of adenosine triphosphatase and other phosphatases as measured by histochemical techniques. J. Histochem. Cytochem., 3, 161-169, 1955.

8) Dubowitz, V.: Mulscle biopsy: A practical approach, 2nd ed. p. 19-40, Balliere Tindall, London, 1985.

9) Lowey, S. an Risby, D. : Light chains from fast and slow muscle myosins. Nature, 234, 81-85, 1971.

10) Schr $\phi$ der, H.D. and Reske-Nielsen, E.: Fiber types in the striated urethral and anal sphincters. Acta Neuropathol., 60, 278-282, 1987.

11）熊谷 章：ヒト外尿道括約筋及びその神経支配に 関する超微的研究. 日泌尿会誌, 77, 930-937, 1986.

12）徳中荘平, 岡村廉晴, 大橋健児, 八竹 直, 村上梅 司：O'Farrell の 2 次元電気泳動法による雄家鬼 外尿道括約筋の解析. 日泌尿会誌, 75, 1956-1963, 1984.

13) Tokunaka, S., Murakami, U., Okamura, K., Miyata,M. an Yachiku, S.: The fiber type of the rabbits' striated external urethral sphincter: Electrophoretic analysis of myosin.J. Urol., 135, 427-430, 1986.

14）岡村廉晴, 徳中茫平, 藤井敬三, 宮田昌伸, 八竹 直：家鬼外尿道括約筋の検討一ATPase 染色を用 いた組織化学的解析一. 日泌尿会誌, 投稿中.

15) Etlinger, J.D., Zak, R. and Fischman, D.A.: Compositional studies of myofibrils from rabbit striated muscle. J. Cell Biol., 68, 123-141, 1976.

16) Szent-Györgyi, A.: Chemistry of Muscular Contraction, 2nd ed., p. 144, Academic Press, New York, 1951.

17) O'Farrell, P.H.: High resolution two-dimensional electrophoresis of proteins.J. Biol. Chem., 250, 4007-4021, 1975.

18) Bradford, M.M.: A rapid and sensitive method for the quantitation of microgram quantities of protein utilizing the principle of protein-dye binding. Anal. Biochem., 72, 248-254, 1976.

19) Hoh, J.F.Y., McGrath, P.A. and White, R.I.: Electrophoretic analysis of multiple forms of myosin in fast twitch and slow twitch muscles of the chick. Biochem. J., 157, 87-95, 1976. 
20) Allington, W.B., Cordry, A.L., McCullough, G. A., Mitchell, D.E. and Nelson, J.W.: Electrophoretic concentration of macromolecules. Anal. Biochem. 85, 188-196, 1978.

21) Fenner, C., Traut, R.R., Mason, D.T and Wikman-Coffelt, J.: Quantification of coomassie blue stained proteins in polyacrylamide gels based on analysis of eluted dye. Anal. Biochem., 63, 595-602, 1975.

22) Fitzsimons, R.B. and Hoh, J.F.Y.: Embryonic and foetal myosins in human skeletal muscle. J. Neurol. Sci., 52, 367-384, 1981.

23) Kelly, M.A.: Emergence of specialization in skeletal muscle. In Handbook of Physiology, Section 20, Skeletal muscle, Peachey, L.D., Adrian, R.H. and Geiger, S.R., 1st. ed., p. 507 -537, Williams \& Wilkins Co., Baltimore, 1983.

24）石川春津, 山田英智: 筋の微細構造. 筋肉病学, 里 吉営二郎, 豊倉康夫, 第 1 版. p. 21 , 南江堂, 東 京, 1973 .

25) Oelrich, T.M.: The urethral sphincter muscle in the male. Am. J. Anat., 158, 229-246, 1980.

26）北沢俊雄：グリセリン筋。生化学実験講座 15 , 筋 肉, 第 1 版, p. 281, 東京化学同人, 東京, 1975 .

27) d'Albis, A., Pantaloni, C. and Bechet, J.: An electrophoretic study of native myosin isozymes and of their subuint content. Eur. J. Biochem., 99, 261-272, 1979.

28) Fardeau, M., Godet-Guillain, J., Tome, F.M.S., Carson, S. and Whalen, R.G. : Congenital neuromuscular disorders: A critical review. In Current topics in Nerve and Muscle Research, Aguayo, A.J. and Karpati, G., 1st ed., p. 164 -177, Excrepta Medica, Amsterdam, 1978.
29) Giometti, C.S., Anderson, N.G. and Anderson, N.L.: Muscle protein analysis. I. Highresolution two-dimensional elcetrophoresis of skeletal muscle proteins for analysis of small biopsy samples. Clin. Chem., 25, 1877-1884, 1979.

30) Ishiura, S., Takagi, A., Nonaka, I. and Sugita, H.: Heterogenous expression of myosin light chain 1 in a human slow twitch muscle fiber. J. Biochem., 90, 279-282, 1981.

31) Billeter, R., Heizmann, C.W., Howald, H. and Jenny, E.: Analysis of myosin light and heavy chain types in single human skeletal muscle fibres. Eur. J. Biochem., 116, 389-395, 1981.

32) Bazeed, M.A., Thuroff, J.W., Schmidt, R.A. and Tanagho, E.A. : Histochemical study of urethral striated musculature in the dog. J. Urol., 128, 406-410, 1982.

33) Dubowitz, V.: Muscle biopsy: A practical approach, 2nd ed. p. 71-73, Balliere Tindall, London, 1985.

34）佐藤達夫, 佐藤健次：肛門挙筋と外肛門括約筋の 神経支配。神経内科， 10，313-320，1979.

35) Elbadawi, A and Atta, M.A.: Ultrastructure of vesicourethral innervation: IV. Evidence for somatomotor plus autonomic innervation of the male feline rhabdosphincter. Neurology and Urodynamics, 4, 23-36, 1985.

36) Price, K.M., Littler, W.A. and Cummins, P.: Human atrial and ventricular mysin light-chain subunits in the adult and during development. Biochem. J., 191, 571-580, 1980, 116, 1986.

(1987午 9 月28日受理) 